\title{
Prediksi Penjualan Barang Menggunakan Metode Adaptive Neuro-Fuzzy Inference System (ANFIS)
}

\author{
Allyna Virrayyani ${ }^{{ }^{*}}$, Sutikno ${ }^{1}$ \\ ${ }^{1}$ Departemen Ilmu Komputer/Informatika \\ Universitas Diponegoro \\ *allynavirrayyani@gmail.com, tik@undip.ac.id
}

\begin{abstract}
ABSTRAK
Prediksi penjualan barang merupakan salah satu cara untuk menjaga stabilitas penjualan barang. Hasil prediksi yang diperoleh dapat dijadikan pertimbangan untuk mengambil keputusan dalam perencanaan manajemen bisnis. Salah satu metode yang dapat digunakan untuk prediksi adalah Adaptive Neuro-Fu₹zy Inference System (ANFIS). Di dalam penelitian ini, ANFIS diimplementasikan dalam sebuah aplikasi sistem prediksi penjualan barang. Prosedur prediksi menggunakan analisis runtun waktu. Aturan ANFIS menggunakan model fuzzy Takagi-Sugeno dan fungsi keanggotaan tipe generalized bell dengan 2 data masukan untuk 1 data target. Pelatihan dan pengujian ANFIS untuk semua produk menghasilkan Mean Absolute Percentage (MAPE) rata-rata pelatihan sebesar 8,73\% dan MAPE rata-rata pengujian sebesar 13,58\%. Hasil MAPE pengujian tersebut kurang dari batas toleransi error, yaitu $20 \%$. Batas toleransi tersebut berdasarkan penafsiran Batey dan Friedrich di mana MAPE $<10 \%$ merupakan perkiraan yang sangat baik dan $10 \%<\mathrm{MAPE}<20 \%$ merupakan perkiraan yang baik. Aplikasi sistem telah diuji menggunakan pengujian black-box. Seluruh prosedur pengujian dinyatakan berhasil.
\end{abstract}

Kata kunci : prediksi, penjualan barang, Adaptive Neuro-Fuzzy Inference System, model fuz:y Takagi-Sugeno

\section{Pendahuluan}

Dewasa ini banyak anggota masyarakat telah mendirikan usaha baik makro maupun mikro untuk menyemarakkan persaingan di dunia wirausaha. Bidang usaha yang digeluti pun bermacam-macam, salah satunya adalah bidang perdagangan. Keuntungan yang didapat dari usaha di bidang perdagangan relatif besar.

Seiring dengan perkembangan teknologi informasi, telah banyak sistem informasi yang digunakan untuk menunjang keberhasilan sebuah usaha. Beberapa sistem informasi yang telah diimplementasikan telah dilengkapi dengan aplikasi prediksi penjualan barang. Penjualan barang merupakan hal yang penting dalam sebuah usaha. Ini karena pendapatan suatu usaha berasal dari hasil penjualan barang. Pendapatan tersebut akan digunakan kembali sebagai modal.

Permasalahan di atas dapat diatasi dengan memprediksi penjualan barang untuk perencanaan manajemen bisnis. Prosedur prediksi yang dapat digunakan adalah analisis runtun waktu, sebuah prosedur statistika yang diterapkan untuk meramalkan struktur probalititas keadaan yang akan datang dalam rangka pengambilan keputusan.
Salah satu metode yang dapat digunakan untuk memprediksi adalah metode Adaptive Neuro-Fuzay Inference System (ANFIS). Contoh dari penerapan dari metode ini yaitu untuk memprediksi distribusi temperatur, diagnosis penyakit diabetes, prediksi penyakit kanker, prediksi performasi akademik siswa, pertumbuhan perdagangan online, dan prediksi kerusakan mesin [1]-[5].

Pada penelitian lain, ANFIS telah diterapkan dalam analisis data runtun waktu yang dibandingkan dengan metode ARIMA [6]. Hasilnya, metode ANFIS lebih baik dari ARIMA. ANFIS juga telah digunakan untuk memprediksi laba atas harga saham Indeks Bursa Efek Istanbul (ISE) [7]. ANFIS berhasil memperkirakan monthly return ISE National 100 Index dengan tingkat akurasi 98,3\%. ANFIS juga telah digunakan untuk peramalan beban listrik jangka pendek yang dibandingkan dengan hasil peramalan menggunakan metode Artificial Neural Network (ANN) [8]. Dari simulasi yang dilakukan, diperoleh nilai Mean Absolute Percentage Error (MAPE) peramalan menggunakan ANFIS sebesar 0,000293275\%, sedangkan MAPE peramalan menggunakan ANN sebesar 0,160443776\%. Penelitian-penelitian yang telah dilakukan membuktikan bahwa metode ANFIS dapat digunakan sebagai metode prediksi. 
Penelitian ini telah merancang sebuah aplikasi prediksi penjualan barang menggunakan metode Adaptive Neuro-Fuzzy Inference System (ANFIS). Studi kasus diambil di salah satu usaha yang begerak di bidang perdagangan yaitu swalayan "Intan Permai". Swalayan "Intan Permai" telah menggunakan sistem informasi jual-beli. Namun sistem informasi tersebut belum dilengkapi dengan sebuah fasilitas prediksi penjualan barang pada waktu yang akan datang.

\section{Metode Penelitian}

Sistem prediksi penjualan barang di swalayan "Intan Permai" dibangun dengan menggunakan model proses waterfall seperti ditunjukkan pada Gambar 1. Tahap awal proses waterfall adalah analisis dan definisi persyaratan. Tahap kedua proses waterfall adalah perancangan sistem. Pada tahap kedua proses waterfall, perancangan sistem dibuat secara rinci sehingga memudahkan proses selanjutnya yaitu proses implementasi. Kemudian tahap ketiga dan keempat proses waterfall yakni implementasi dan pengujian sistem [9].

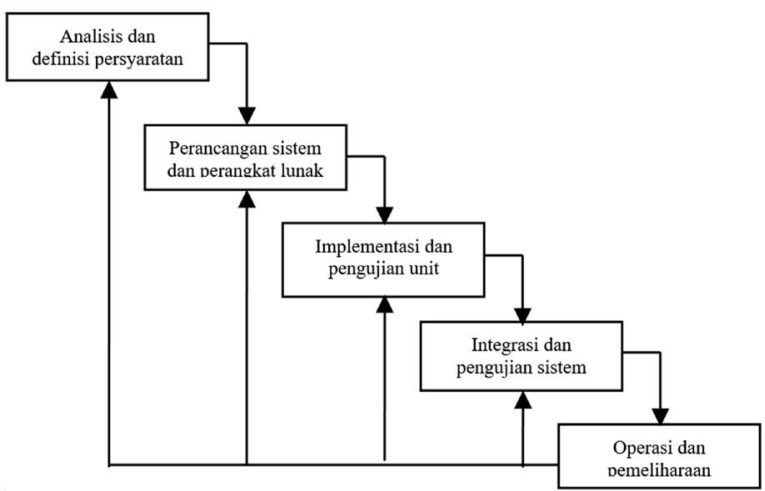

Gambar 1. Siklus hidup perangkat lunak [9]

\section{Hasil dan Pembahasan}

\subsection{Arsitektur sistem}

Arsitektur sistem prediksi penjualan barang dibuat berdasarkan model aplikasi sistem berbasis web yang direpresentasikan pada Gambar 2. Terdapat 4 elemen dalam arsitektur sistem prediksi penjualan barang ini, yaitu pengguna, web server, aplikasi prediksi penjualan barang, dan server basis data. Pada elemen pengguna, terdapat tiga macam pengguna yaitu admin, operator, dan pengguna umum. Pengguna mengirimkan request melalui web server kemudian web server tersebut meneruskannya ke aplikasi prediksi penjualan barang. Aplikasi tersebut mengolah request dari pengguna. Aplikasi prediksi penjualan barang berinteraksi dengan basisdata server untuk mengambil maupun menyimpan data. Kemudian response dikirim ke pengguna melalui web server.

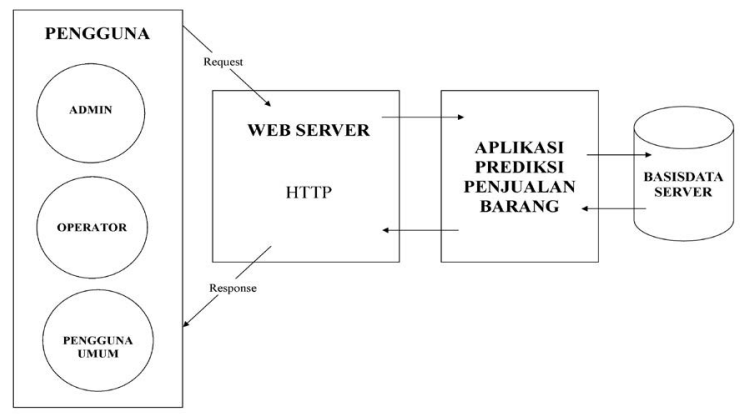

Gambar 2. Arsitektur sistem prediksi penjualan barang

\subsection{Pemodelan Data}

Hubungan data di dalam aplikasi prediksi penjualan barang digambarkan dalam sebuah ERD seperti pada Gambar 3. Di dalam ERD, terdapat 6 entitas yaitu total_ penjualan, data_latih_uji, hasil_prediksi, data_barang, variabel_latih_uji, dan pengguna.

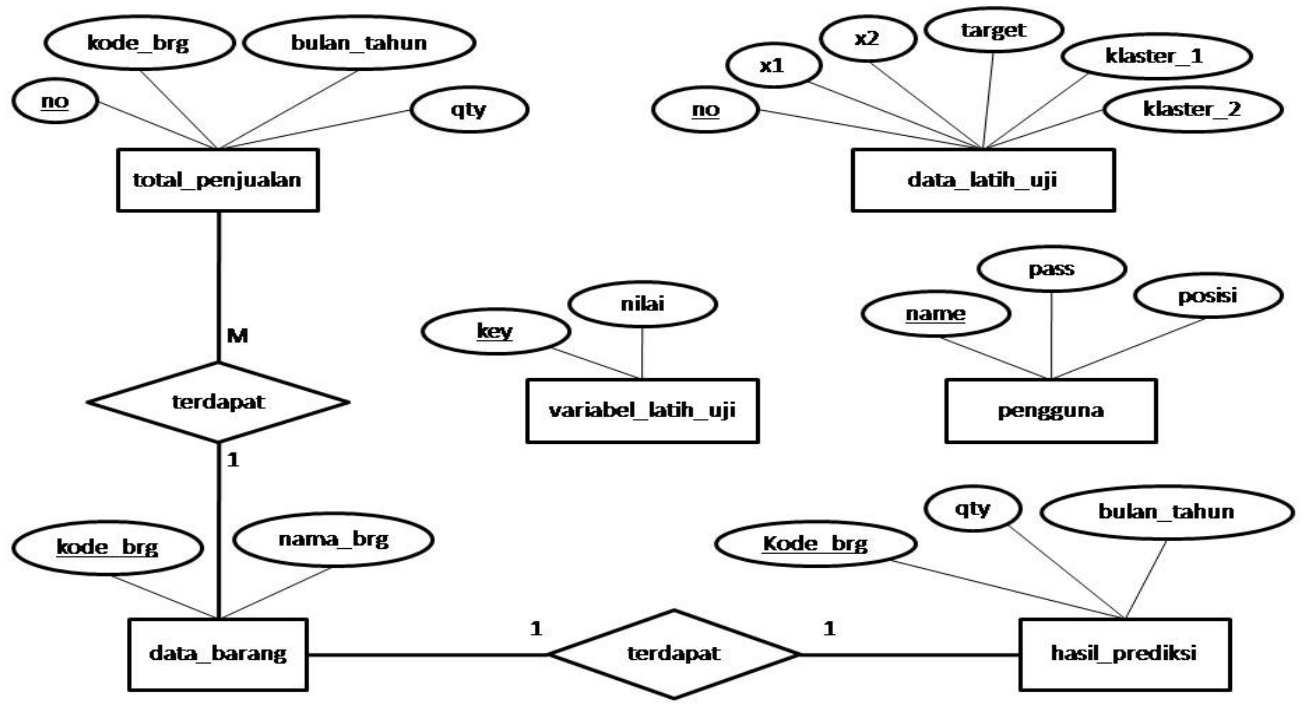

Gambar 3. ERD aplikasi prediksi penjualan barang 


\subsection{Perancangan Proses}

Perancangan proses pada aplikasi sistem prediksi penjualan barang dibuat berdasarkan proses penghitungan yang terdapat dalam aplikasi sistem. Perancangan proses dibuat dengan menggunakan flowchart. Perancangan proses secara keseluruhan dijelaskan pada Gambar 4. Sedangkan proses pengelompokan data menggunakan Furzy C-Means (FCM) dijabarkan menggunakan flowchart pada Gambar 5, perancangan proses pelatihan alur maju pada Gambar 6 dan proses pelatihan alur mundur seperti pada Gambar 7.

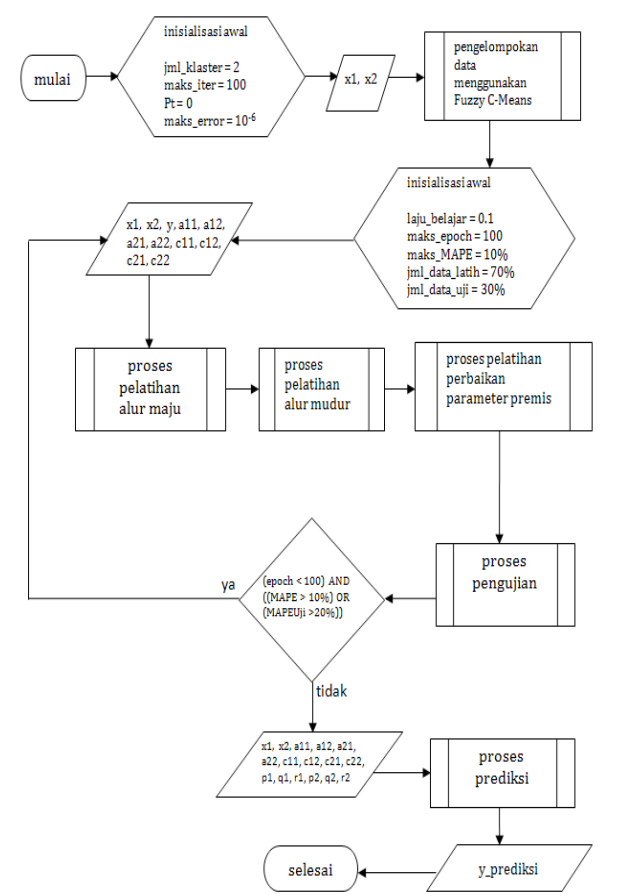

Gambar 4. Flowchart perancangan proses aplikasi sistem prediksi penjualan barang

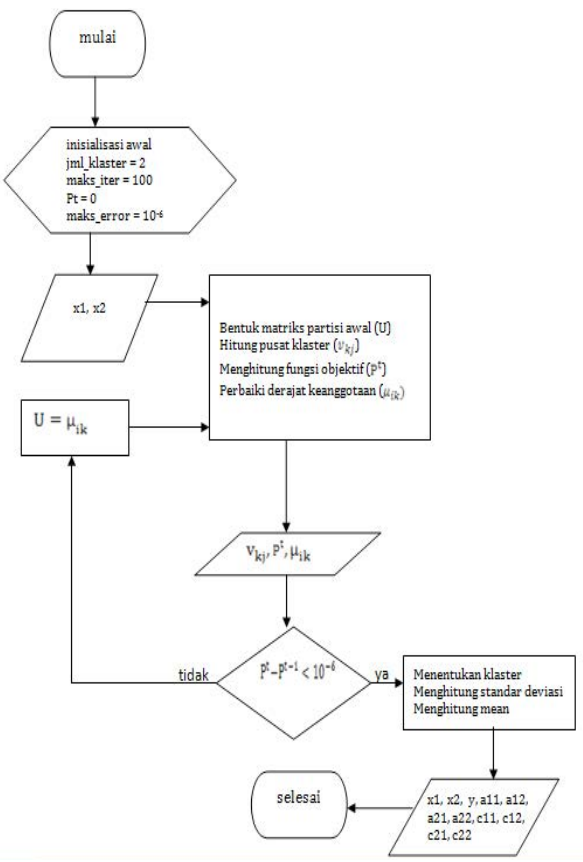

Gambar 5. Flowchart pengelompokan data menggunakan Fuгzy C-Means
Keterangan Gambar 4 dan 5:

: Penjualan barang 2 tahun sebelumnya

$\mathrm{x} 2$

: Penjualan barang 1 tahun sebelumnya

y

: Penjualan barang sekarang

a11, a12, a21, a22 : parameter premis a (standar deviasi)

c11, c12, c21, c22 : parameter premis c (mean)

p1, q1, r1, p2, q2, r2: parameter konsekuen

$\mathrm{v}_{\mathrm{kj}} \quad$ : pusat klaster

$\mathrm{P}^{\mathrm{t}} \quad$ : fungsi objektif

$\mu_{\mathrm{ik}} \quad:$ derajat keanggotaan data

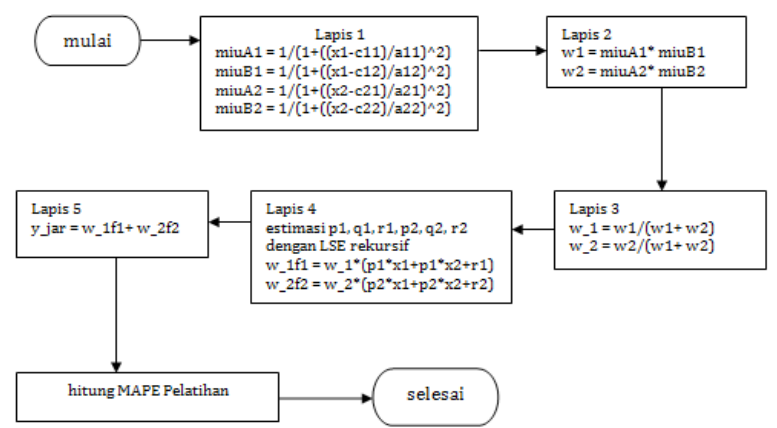

Gambar 6. Flowchart proses pelatihan alur maju

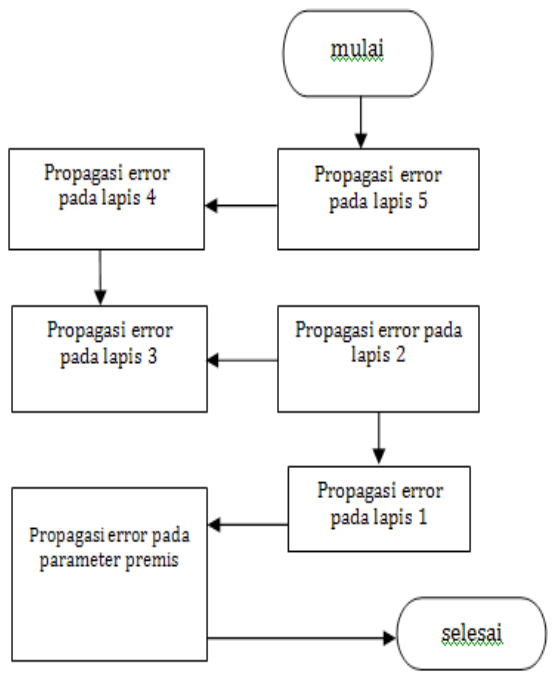

Gambar 7. Flowchart proses pelatihan alur mundur

\subsection{Antarmuka}

Antarmuka utama yang terdapat pada aplikasi ini terdiri dari 4 antarmuka yaitu antarmuka halaman utama, antarmuka data barang, antarmuka pelatihan dan pengujian dan antarmuka hasil prediksi. Penjelasan masing-masing antarmuka tersebut yaitu sebagai berikut.

\section{A. Antarmuka Halaman Utama}

Halaman utama aplikasi prediksi penjualan barang muncul ketika pengguna memanggilnya melalui browser. Implementasi antarmuka halaman utama disajikan pada Gambar 8. 


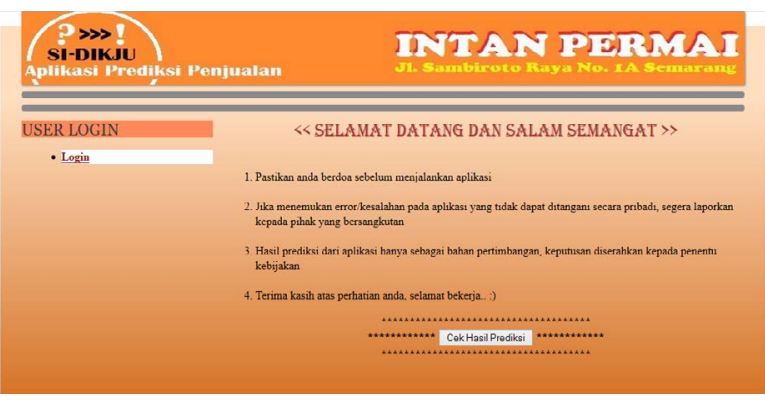

Gambar 8. Antarmuka halaman utama

\section{B. Antarmuka Data Barang}

Ketika pengguna menekan link Data Barang, maka muncul tampilan halaman utama data barang. Implementasi antarmuka halaman tersebut disajikan pada Gambar 9.

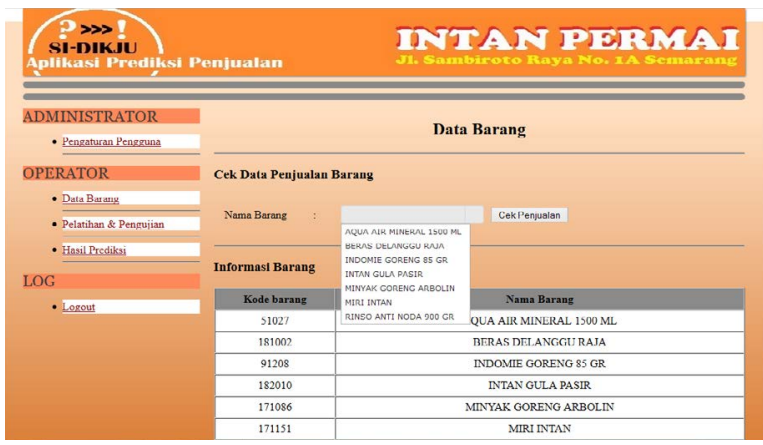

Gambar 9. Antarmuka halaman utama data barang

\section{Antarmuka Halaman Pelatihan \& Pengujian}

Implementasi antarmuka halaman Pelatihan dan Pengujian disajikan pada Gambar 10. Antarmuka ini digunakan untuk melakukan proses pelatihan dan pengujia dari algoritma yang digunakan yaitu Adaptive Neuro-Fuz:yy Inference System (ANFIS).

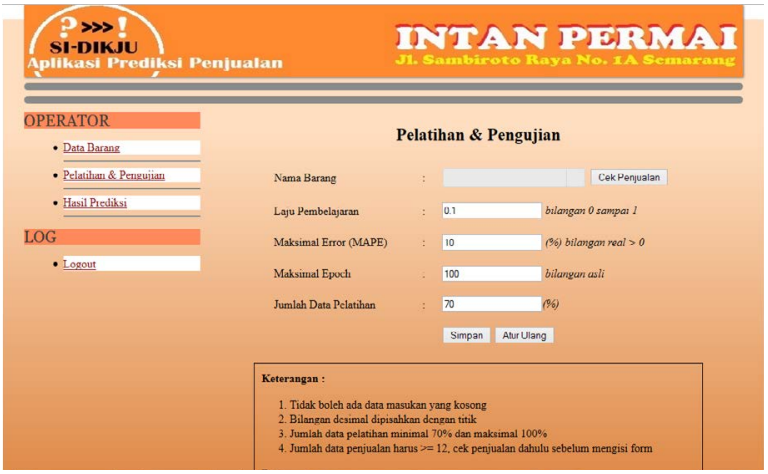

Gambar 10. Antarmuka halaman utama pelatihan \& pengujian

\section{Antarmuka Hasil Prediksi}

Ketika pengguna menekan link Hasil Prediksi, maka muncul tampilan halaman utama hasil prediksi. Jika hasil prediksi masih kosong, maka muncul tampilan halaman yang menginformasikan bahwa data hasil prediksi masih kosong. Jika data prediksi tidak kosong, maka muncul tampilan halaman yang menampilkan seluruh hasil prediksi. Antarmuka halaman tersebut disajikan pada Gambar 11.

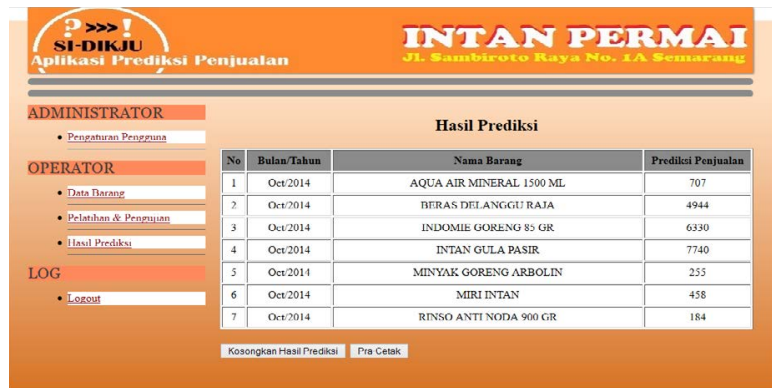

Gambar 11. Antarmuka tampilan seluruh hasil prediksi

\subsection{Pengujian}

Komponen data yang dipakai pada pengujian ini merupakan data penjualan barang di swalayan "Intan Permai". Produk yang dipilih berjumlah 7 buah. Rincian penjualan produk-produk tersebut dijabarkan pada Tabel 1. Kemudian dari data tersebut dilakukan proses inisialisasi awal berupa pembentukan variabel input berupa $\mathrm{x}_{1}$ dan $\mathrm{x}_{2}$ dan variabel output berupa y. Inisialisasi tersebut berdasarkan metode analisis runtun waktu di mana $x_{1}$ merupakan jumlah penjualan 2 bulan sebelum waktu sekarang, $\mathrm{x}_{2}$ merupakan jumlah penjualan 1 bulan sebelum waktu sekarang, dan y merupakan penjualan pada waktu sekarang. Contoh hasil dari proses inisialisasi awal untuk penjualan beras delanggu seperti pada Tabel 2. Data hasil proses ini digunakan sebagai data pelatihan dan pengujian dengan komposisi data pelatihan berjumlah 22 data yaitu data ke-1 sampai dengan ke-22 dan data pengujian berjumlah 9 yaitu data ke-23 sampai dengan data ke-31. Sedangkan nilai Mean Absolute Percentage Error (MAPE) hasil dari proes pelatihan dan pengujian tiap produk dijabarkan pada Tabel 3. Variable awal yang diberikan pada algoritma Adaptive Neuro-Fuzay Inference System (ANFIS) yaitu sebagai berikut:
a. Laju pembelajaran $: 0.1$
b. Maksimal (MAPE) : $10 \%$
c. Maksimal epoch $\quad: 100$
d. Jumlah data pelatihan : 22
e. Jumlah data pengujian : 9

Tabel 1. Detail penjualan barang

\begin{tabular}{llccccccc}
\hline No & Bulan/Tahun & $\begin{array}{c}\text { Beras } \\
\text { Delanggu } \\
\text { Raja }\end{array}$ & $\begin{array}{c}\text { Aqua Air } \\
\text { Mineral } \\
\mathbf{1 5 0 0} \mathbf{~ m l}\end{array}$ & $\begin{array}{c}\text { Indomie } \\
\text { Goreng } \\
\mathbf{8 5} \mathbf{~ g r}\end{array}$ & $\begin{array}{c}\text { Intan } \\
\text { Gula } \\
\text { Pasir }\end{array}$ & $\begin{array}{c}\text { Minyak } \\
\text { Goreng } \\
\text { Arbolin }\end{array}$ & $\begin{array}{c}\text { Miri } \\
\text { Intan }\end{array}$ & $\begin{array}{c}\text { Rinso Anti } \\
\text { Noda 900 } \\
\text { gr }\end{array}$ \\
\hline 1 & Januari/2012 & 4709 & 287 & 5001 & 5171 & 208 & 299 & 118 \\
2 & Februari/2012 & 4493 & 406 & 5749 & 6632 & 252 & 431 & 169 \\
3 & Maret/2012 & 5071 & 468 & 5600 & 6914 & 270 & 436 & 230
\end{tabular}




\begin{tabular}{|c|c|c|c|c|c|c|c|c|}
\hline No & Bulan/Tahun & $\begin{array}{c}\text { Beras } \\
\text { Delanggu } \\
\text { Raja } \\
\end{array}$ & $\begin{array}{c}\text { Aqua Air } \\
\text { Mineral } \\
1500 \mathrm{ml}\end{array}$ & $\begin{array}{c}\text { Indomie } \\
\text { Goreng } \\
85 \mathrm{gr} \\
\end{array}$ & $\begin{array}{c}\text { Intan } \\
\text { Gula } \\
\text { Pasir } \\
\end{array}$ & $\begin{array}{l}\text { Minyak } \\
\text { Goreng } \\
\text { Arbolin }\end{array}$ & $\begin{array}{c}\text { Miri } \\
\text { Intan }\end{array}$ & $\begin{array}{c}\text { Rinso Anti } \\
\text { Noda } 900 \\
\text { gr }\end{array}$ \\
\hline 4 & April/2012 & 4753 & 517 & 5623 & 8066 & 246 & 420 & 230 \\
\hline 5 & Mei/2012 & 5099 & 530 & 5591 & 8838 & 291 & 454 & 338 \\
\hline 6 & Juni/2012 & 4698 & 520 & 6087 & 8734 & 337 & 399 & 234 \\
\hline 7 & Juli/2012 & 4688 & 479 & 6705 & 9273 & 364 & 443 & 170 \\
\hline 8 & Agustus/2012 & 4981 & 528 & 5371 & 7899 & 337 & 561 & 216 \\
\hline 9 & September/2012 & 4561 & 732 & 6191 & 8309 & 372 & 434 & 267 \\
\hline 10 & Oktober/2012 & 4713 & 814 & 5940 & 8767 & 553 & 492 & 241 \\
\hline 11 & Nopember/2012 & 4892 & 722 & 5745 & 7733 & 662 & 420 & 197 \\
\hline 12 & Desember/2012 & 6080 & 567 & 6502 & 7840 & 733 & 466 & 234 \\
\hline 13 & Januari/2013 & 5882 & 538 & 6021 & 7126 & 787 & 455 & 222 \\
\hline 14 & Februari/2013 & 4632 & 451 & 5310 & 6782 & 707 & 415 & 167 \\
\hline 15 & Maret/2013 & 5848 & 643 & 5492 & 7417 & 757 & 397 & 244 \\
\hline 16 & April/2013 & 5573 & 632 & 5090 & 7524 & 704 & 323 & 218 \\
\hline 17 & Mei/2013 & 6406 & 801 & 5837 & 7982 & 795 & 468 & 212 \\
\hline 18 & Juni/2013 & 6290 & 662 & 6473 & 8333 & 746 & 419 & 183 \\
\hline 19 & Juli/2013 & 6061 & 634 & 6693 & 9125 & 757 & 547 & 200 \\
\hline 20 & Agustus/2013 & 3634 & 658 & 4763 & 5820 & 406 & 418 & 177 \\
\hline 21 & September/2013 & 3181 & 761 & 4763 & 6679 & 353 & 360 & 154 \\
\hline 22 & Oktober/2013 & 3435 & 898 & 5476 & 8233 & 395 & 461 & 186 \\
\hline 23 & Nopember/2013 & 3854 & 706 & 5120 & 6761 & 385 & 384 & 219 \\
\hline 24 & Desember/2013 & 3994 & 580 & 4988 & 6621 & 336 & 372 & 270 \\
\hline 25 & Januari/2014 & 4739 & 557 & 5713 & 6123 & 316 & 447 & 291 \\
\hline 26 & Februari/2014 & 3951 & 493 & 4459 & 5397 & 235 & 353 & 236 \\
\hline 27 & Maret/2014 & 4415 & 780 & 4489 & 6599 & 256 & 379 & 230 \\
\hline 28 & April/2014 & 4054 & 867 & 5042 & 6869 & 294 & 343 & 285 \\
\hline 29 & Mei/2014 & 4557 & 952 & 5079 & 6472 & 289 & 363 & 194 \\
\hline 30 & Juni/2014 & 4327 & 729 & 5737 & 6464 & 233 & 379 & 241 \\
\hline 31 & Juli/2014 & 4545 & 585 & 5576 & 5600 & 234 & 390 & 211 \\
\hline 32 & Agustus/2014 & 5056 & 880 & 7113 & 7347 & 218 & 427 & 243 \\
\hline 33 & September/2014 & 4776 & 1103 & 5945 & 8352 & 241 & 456 & 199 \\
\hline
\end{tabular}

Tabel 2. Data pelatihan dan pengujian untuk produk Beras Delanggu Raja

\begin{tabular}{cccc}
\hline \multirow{2}{*}{ Data ke- } & \multicolumn{3}{c}{ Beras Delanggu Raja } \\
\cline { 2 - 4 } & $\mathbf{x}_{1}$ & $\mathbf{x}_{2}$ & $\mathbf{y}$ \\
\hline 1 & 4709 & 4493 & 5071 \\
2 & 4493 & 5071 & 4753 \\
3 & 5071 & 4753 & 5099 \\
4 & 4753 & 5099 & 4698 \\
5 & 5099 & 4698 & 4688 \\
6 & 4698 & 4688 & 4981 \\
7 & 4688 & 4981 & 4561 \\
8 & 4981 & 4561 & 4713 \\
9 & 4561 & 4713 & 4892 \\
10 & 4713 & 4892 & 6080
\end{tabular}




\begin{tabular}{|c|c|c|c|}
\hline \multirow{2}{*}{ Data ke- } & \multicolumn{3}{|c|}{ Beras Delanggu Raja } \\
\hline & $\mathrm{x}_{1}$ & $\mathrm{x}_{2}$ & $\mathrm{y}$ \\
\hline 11 & 4892 & 6080 & 5882 \\
\hline 12 & 6080 & 5882 & 4632 \\
\hline 13 & 5882 & 4632 & 5848 \\
\hline 14 & 4632 & 5848 & 5573 \\
\hline 15 & 5848 & 5573 & 6406 \\
\hline 16 & 5573 & 6406 & 6290 \\
\hline 17 & 6406 & 6290 & 6061 \\
\hline 18 & 6290 & 6061 & 3634 \\
\hline 19 & 6061 & 3634 & 3181 \\
\hline 20 & 3634 & 3181 & 3435 \\
\hline 21 & 3181 & 3435 & 3854 \\
\hline 22 & 3435 & 3854 & 3994 \\
\hline 23 & 3854 & 3994 & 4739 \\
\hline 24 & 3994 & 4739 & 3951 \\
\hline 25 & 4739 & 3951 & 4415 \\
\hline 26 & 3951 & 4415 & 4054 \\
\hline 27 & 4415 & 4054 & 4557 \\
\hline 28 & 4054 & 4557 & 4327 \\
\hline 29 & 4557 & 4327 & 4545 \\
\hline 30 & 4327 & 4545 & 5056 \\
\hline 31 & 4545 & 5056 & 4776 \\
\hline
\end{tabular}

Tabel 3. Nilai Mean Absolute Percentage Error (MAPE) pelatihan dan pengujian

\begin{tabular}{clll}
\hline No & \multicolumn{1}{c}{ Nama Produk } & \multicolumn{1}{c}{ MAPE Pelatihan } & \multicolumn{1}{c}{ MAPE Pengujian } \\
\hline 1 & Aqua Air Mineral 1500 ml & $9.3058095522 \%$ & $19.8423236744 \%$ \\
2 & Beras Delanggu Raja & $7.5343642644 \%$ & $9.4180332828 \%$ \\
3 & Indomie Goreng 85 gr & $4.9419995960 \%$ & $11.6435485586 \%$ \\
4 & Intan Gula Pasir & $8.4451988528 \%$ & $13.1059485802 \%$ \\
5 & Minyak Goreng Arbolin & $11.6431502969 \%$ & $12.9677849177 \%$ \\
6 & Miri Intan & $9.2810562284 \%$ & $9.4778460841 \%$ \\
7 & Rinso Anti Noda 900 gr & $9.9380098438 \%$ & $18.5979953479 \%$ \\
\hline
\end{tabular}

Batas tolerasi MAPE pengujian adalah 20\% sedangkan nilai MAPE pengujian seluruh produk lebih kecil dari batas toleransi MAPE pengujian. Sehingga dapat disimpulkan bahwa hasil pelatihan dan pengujian seluruh produk diterima.

\section{Kesimpulan}

Berdasarkan hasil pengujian algoritma Adaptive Neuro-Fuzzy Inference System (ANFIS), didapatkan nilai Mean Absolute Percentage Error (MAPE) pengujian untuk seluruh produk di bawah batas tolerasi error atau di bawah $20 \%$. Sehingga dapat disimpulkan bahwa metode ANFIS cukup baik untuk digunakan sebagai metode prediksi penjualan barang.

\section{Daftar Pustaka}

[1] W. Jiyun, p. Geng \& d. Wei, Prediction of online trade growth using search-ANFIS: Transactions on Taobao as examples, IEEE International Conference on Fuzzy Systems, Beijing, 2014.

[2] H.B. Zhang, Y.F. Huang, S.X. Sun \& Y. Zhao, Application of ANFIS in engine fault prediction, Applied Mechanics and Materials, Vol. 651-653, pp. 651-654,2014.

[3] I. Develi \& U. Sorgucu, Prediction of temperature distribution in human BEL exposed to $900 \mathrm{MHz}$ mobile phone radiation using ANFIS, Applied Soft Computing Journal, Vol. 37, pp. 1029-1036, 2015. 
[4] C. Kalaiselvi \& G.M. Nasira, A new approach for diagnosis of diabetes and prediction of cancer using ANFIS, 2014 World Congress on Computing and Communication Technologies, WCCCT 2014, pp. 188-190, Tapilnadu, 2014.

[5] J.F. Chen \& Q.H. Do, Prediction of student academic performance using an ANFIS approach, International Journal of Information and Management Sciences, vol. 25, issue 4, pp. 371-389, 2014.

[6] A.H Saputra,., Tarno\& B. Warsito, Analisa Data Runtun Waktu dengan Metode Adaptive Neuro-Fur:y Inference System (ANFIS). Jurnal Gaussian, Vol. 1, No. 1, pp. 31-40, 2012.
[7] M.A. Boyacioglu, \& D. Avci, An Adaptive NetworkBased Fuzzy Inference System (ANFIS) for The Prediction of Stock Market Return : The Case of Istanbul Stock Exchange. Elsevier, Vol. 37, pp.79087912, 2010.

[8] Syukriyadin \& R. Syahputra, Prakiraan Beban Listrik Jangka Pendek Kota Banda Aceh Berbasis Logika Fuzzy, Jurnal Rekayasa Elektrika, Vol. 1, No. 1, pp. 46-51, 2012.

[9] I. Sommervile, 2003. Rekayasa Perangkat Lunak. 6th ed. Jakarta: Erlangga. 